McElroy, L. W. \& Goss, H. (1940b). F. Nutrit. 20, 54 I.

McFlroy, L. W. \& Goss, H. (194Ia). F. Nutrit. 21, 163.

McElroy, L. W. \& Goss, H. (194I b). F. Nutrit. 21, 405.

Miller, R. F., Hart, G. H. \& Cole, H. H. (1942). Bull. Calif. agric, Exp. Sta. no. 672, p. 31.

Piercy, S. E. (1934a). Vet. F. 90, 53.

Piercy, S. E. $(193+b)$. Vet $\mathcal{F} .90,223$.

Reakes, H. (1910). Ann. Rep. Dep. Agric. N.Z, no. 18.

Richardson, A. E. V., Trumble, H. C. \& Shapter, R. E. (193 I). Bull. Coun. sci. industr. Res. Aust. no. 49.

Shearer, G. D. \& Stewart, J. (1931). Rep. Inst. Anim. Path. Univ. Camb. no. 2, p. 86.

Stewart, J. (1934-5). Rep. Inst. Anim. Path. Univ. Camb. no. 4, p. I79.

Stewart, J. \& Shearer, G. D. (1932-3). Rep. Inst. Anim. Path. Univ. Camb. no. 3, p. 87.

Stewart, W. L. (1933). Vet. F. 89, 63.

Theiler, A. (1934). Vet. 7. 90, 143.

Theiler, A., Green, H. H. \& Du Toit, P. J. (1924). F. Dep. Agric. S. Afr. 8, 460.

Thomas, B. H., La Grange, W. F. \& Culbertson, C. C. (1942). Y. Anim. Sci. 1, 61.

Tisdall, F. F. \& Brown, A. (1929). F. Amer. med. Ass. 92, 860.

Woodman, H. F. \& Evans, R. E. (1930). J. agric. Sci. 20, 587.

Wright, C. M. \& Taylor, N. H. (1931). N.Z. F. Sci. Tech. r3, sect. A, p. 57.

\title{
Rickets in Sheep
}

\section{Measurement of Phosphorus Absorption}

\author{
By T. K. EWER (Animal Health Trust Fellow) \\ Department of Animal Pathology, University of Cambridge*
}

(Received 17 fune 1950)

A previous paper (Ewer, 195 I) described the production of rickets in lambs by means of a diet low in vitamin $\mathrm{D}$ and phosphorus and high in calcium, and the clinical effect of supplementation with vitamin $D$ and phosphorus. Quantitative measurement of the $P$ retention by these sheep forms the subject of the present communication. The value of balance trials in helping to establish quantitatively the absorption of various constituents of an animal's diet is well established. In rickets in the rat, dog and man, $\mathrm{Ca}$ and $\mathrm{P}$ metabolism has been investigated in this way by a number of workers and, in a study of Ca metabolism in sheep, Franklin (1934-5) also made use of the method. Bethke, Kick \& Wilder (1932) reviewed the earlier work of McCollum, Simmonds, Parsons, Shipley \& Park (I920-I) and of Sherman \& Pappenheimer (I920-I) and found that the optimum $\mathrm{Ca}: \mathrm{P}$ ratio for the rat was between $\mathrm{x} \cdot \mathrm{O}$ and $2 \cdot 0$.

It has been shown that the digestibility of many of the major food constituents in a sheep's diet, including dry matter, can be affected by the addition of such things as crude fibre, readily available carbohydrate and nitrogenous compounds (Swift, Thacker, Black, Bratzler \& James, 1947), and that the ash from lucerne hay can increase the digestibility of roughage from ground maize-cobs (Burroughs, Gerlaugh \& Bethke, 1950). Observations were therefore made upon the dry-matter digestibility

- Present address: The Veterinary School, University of Queensland, Fairfield Road, Yeerongpilly, Brisbane, Queensland, Australia. 
of the basal diet following single massive dosage with vitamin $\mathrm{D}_{2}$ and alteration of the $\mathrm{Ca}: \mathrm{P}$ ratio by additional phosphate. It was thought desirable also to investigate the $\mathrm{P}$ metabolism of affected and normal sheep, while they were kept on a rachitogenic diet, and to observe the effect of supplementation by vitamin $D$.

\section{EXPERIMENTAL}

Sheep. The sheep were placed in the usual metal metabolism crate or in a specially constructed raised wooden pen, through the floor of which a hole was bored to allow the passage of a rubber tube connected to a wide-mouth enamel funnel, held in place on the belly of the sheep by a wide rubber band. Faeces were collected in rubberized canvas bags held in position by leather harness. Water was always available to the sheep from troughs clipped to the side of the pen. Analyses indicated that the tap water contained a negligible amount of $\mathrm{P}$, although $\mathrm{Ca}$ was present to the extent of $5.68 \mathrm{mg}$. $/ 100 \mathrm{ml}$. In view of the small quantity of either mineral likely to be added from this source to the total daily intake, tap water was used throughout.

The nervous temperament of the young Welsh sheep used made it necessary to have rather long pre-experimental periods to allow them to become accustomed to pens and harness, as indicated by their general behaviour and the constancy of the food intake.

Food. A representative sample of the food after it had been mixed each morning, and the whole of the residues of the preceding day's feed were taken. It was subsequently found that the maximum variation in the $P$ content of the food residues of any particular sheep from day to day was within $0.1 \mathrm{mg}$. of the mean value. The residues were therefore bulked from each sheep, and after careful mixing, a sample was taken for dry-matter and $\mathrm{P}$ determination. Dry matter was estimated by drying in an electric oven at $100^{\circ}$ to constant weight. Phosphorus was estimated by taking duplicate I g. samples of the dried material after grinding, and ashing them with excess $10 \%$ $\mathrm{Mg}\left(\mathrm{NO}_{3}\right)_{2}$ in a muffle furnace at $54^{\circ}$. The ash was dissolved in $6 \mathrm{~N}-\mathrm{HCl}$, made up to volume and an appropriate portion taken for $\mathrm{P}$ determination according to Gomori's (1942) modification of Fiske \& Subbarow's (1925) method.

Urine. A crystal of thymol was placed in the urine pots and each $24 \mathrm{hr}$. collection measured. After mixing, a $250 \mathrm{ml}$. sample was taken for analysis. Acid-soluble $P$ was determined on a $10 \%$ trichloroacetic-acid filtrate and total $\mathrm{P}$ by wet digestion with $60 \%$ perchloric acid and hydrogen peroxide.

Faeces. The bags were removed at $24 \mathrm{hr}$. intervals and the faeces weighed, dried at $100^{\circ}$ to constant weight and ground. It was found that the daily $\mathrm{P}$ variation in the faeces of any particular sheep compared to a pooled sample was small, so that in most trials the dried faeces of each sheep for the whole trial were ground together and duplicate samples taken for ashing. The $P$ content was determined as for the food.

Exp. I. Six sheep were used, three from a group being given a rachitogenic, low-P diet and three from a group given the same diet but having had a massive dose of vitamin $D_{2}$ by mouth 12 days before. Further details of food and management of the sheep used in this and subsequent experiments will be found in the preceding paper (Ewer, 1951). 
Exp.2. Three sheep that had been receiving the low-P diet and were showing welldeveloped rachitic lesions, as indicated by $\mathrm{X}$-ray examination and blood inorganic- $\mathrm{P}$ values of 1.8 or $1.9 \mathrm{mg} / / 100 \mathrm{ml}$., were compared with three sheep from a high-P group that were clinically normal and had blood inorganic-P levels of between 5.4 and $6.1 \mathrm{mg} . / 100 \mathrm{ml}$.

Exp. 3. This experiment only lasted 6 days, since the sheep were being used primarily for the investigation of the excretion of ${ }^{32}$. Four rachitic sheep and two normal (high-P) sheep were used. At the conclusion of the pre-experimental period, two of the low-P sheep and one of the high-P animals were taken at random and a large dose of vitamin $\mathrm{D}$ was given subcutaneously. The following day, ${ }^{32} \mathrm{P}$ was given intravenously and the experimental period began.

Exp. 4. Observations are reported on only one sheep which served as its own control and was being used in isotopic-P excretion studies. This animal, no. 4, had been rachitic for over 12 months as a result of being kept on the low-P, high-Ca diet. The amount of food offered was set at a level of $203 \circ \mathrm{g}$. daily (wet weight), and during the experiment food residues remained at a constant level.

\section{RESULTS}

Exp. r. The results of the first experiment are summarized in Table $\mathrm{r}$. Although in no way conclusive, they suggest that the vitamin D-treated sheep may have been more nearly in $\mathrm{P}$ balance than the others. Closer examination of the two exceptions revealed that sheep no. 2 had the least rickets according to radiographic evidence, and that sheep no. I 5 was losing weight at the time of the experiment and not long afterwards showed a moderate degree of rickets.

Table 1. Exp. I. Digestibility of dry matter and mean daily retention of phosphorus by the sheep over 10 days

\begin{tabular}{|c|c|c|c|c|c|}
\hline \multirow[b]{2}{*}{$\begin{array}{l}\text { Sheep } \\
\text { no. }\end{array}$} & \multirow[b]{2}{*}{ Diet } & \multicolumn{3}{|c|}{ Dry matter } & \multirow{2}{*}{$\begin{array}{c}\text { Retention } \\
\text { of } P \\
\text { (g.) }\end{array}$} \\
\hline & & $\begin{array}{c}\text { Intake } \\
(\mathrm{g} .)\end{array}$ & $\begin{array}{l}\text { Output } \\
\text { (g.) }\end{array}$ & $\begin{array}{c}\text { Digestibility } \\
(\%)\end{array}$ & \\
\hline $\left.3^{2}\right)$ & \multirow[t]{2}{*}{ Low-P (all sheep rachitic) } & $\left\{\begin{array}{c}439 \cdot 2 \\
406 \cdot 7 \\
\text { (7 days only }\end{array}\right.$ & $\begin{array}{c}90 \cdot 0 \\
96 \cdot 1 \\
7 \text { days only }\end{array}$ & $\begin{array}{l}79 \cdot 5 \\
76 \cdot 4\end{array}$ & $\begin{array}{l}+0.042 \\
-0.093\end{array}$ \\
\hline 18 & & $505 \cdot 6$ & $92 \cdot 9$ & $77 \cdot 7$ & -0.050 \\
\hline $\left.\begin{array}{r}1 \\
6 \\
15\end{array}\right\}$ & $\begin{array}{l}\text { Low-P with vitamin D } \\
\text { (sheep not rachitic) }\end{array}$ & $\left\{\begin{array}{l}116 \cdot 2 \\
255.7 \\
117.9\end{array}\right.$ & $\begin{array}{l}20 \cdot 2 \\
35 \cdot 3 \\
21 \cdot 8\end{array}$ & $\begin{array}{l}82 \cdot 6 \\
86 \cdot 2 \\
81 \cdot 5\end{array}$ & $\begin{array}{l}+0.009 \\
+0.053 \\
-0.085\end{array}$ \\
\hline
\end{tabular}

- Sheep no. 3 , on the 8th day, left nearly half its food and began suddenly to pass watery faeces. On the morning of the 9 th day it was found dead. A post-mortem examination indicated death from enterotoxaemia due to Clostridium welchii type $\mathrm{D}$, which was confirmed by cultural and toxin-antitoxin tests.

The higher digestibility coefficient for the vitamin D-treated sheep should be considered in relation to their very much lower food intake. In the 30-day period before the balance trial started the group from which these sheep were taken con- 
sistently showed a food consumption $21 \%$ lower than that of the unsupplemented low-P group.

Exp. 2. The 3 weeks' preliminary period established the maximum dietary levels at $1200 \mathrm{~g}$. $/ \mathrm{sheep} /$ day for the rachitic sheep and at $2500 \mathrm{~g}$./sheep/day for the normal animals. Table 2 summarizes the data concerning $\mathrm{P}$ absorption and dry-matter digestibility.

Table 2. Exp. 2. Digestibility of dry matter and mean daily retention of phosphorus by the sheep

\begin{tabular}{|c|c|c|c|c|c|}
\hline \multirow[b]{2}{*}{$\begin{array}{l}\text { Sheep } \\
\text { no. }\end{array}$} & \multirow[b]{2}{*}{ Diet } & \multicolumn{3}{|c|}{ Dry matter } & \multirow{2}{*}{$\begin{array}{c}\text { Retention } \\
\text { of } P \\
\text { (g.) }\end{array}$} \\
\hline & & $\begin{array}{c}\text { Intake } \\
(\mathrm{g} .)\end{array}$ & $\begin{array}{l}\text { Output } \\
\text { (g.) }\end{array}$ & $\begin{array}{l}\text { Digestibility } \\
(\%)\end{array}$ & \\
\hline $\left.\begin{array}{r}4 \\
13 \\
20\end{array}\right\}$ & Low-P (all sheep rachitic) & $\left\{\begin{array}{l}411 \cdot 4 \\
409 \cdot 0 \\
421 \cdot 2\end{array}\right.$ & $\begin{array}{l}94 \cdot 9 \\
95 \cdot 5 \\
91 \cdot 0\end{array}$ & $\begin{array}{l}76 \cdot 9 \\
76 \cdot 6 \\
78 \cdot 4\end{array}$ & $\begin{array}{l}-0.089 \\
-0.075 \\
+0.011\end{array}$ \\
\hline $\begin{array}{c}5 \\
10 \\
12\end{array}$ & High-P & $\left\{\begin{array}{l}879 \cdot 7 \\
927 \cdot 9 \\
804 \cdot 2\end{array}\right.$ & $\begin{array}{l}153^{\circ} \circ \\
175^{\circ} \circ \\
145^{\circ} 3\end{array}$ & $\begin{array}{l}82 \cdot 4 \\
81 \cdot 1 \\
81 \cdot 9\end{array}$ & $\begin{array}{l}+0.501 \\
+0.547 \\
+0.621\end{array}$ \\
\hline
\end{tabular}

In view of the clinical condition of the low-P sheep it was not surprising to find that two of them were in negative $P$ balance. The mean daily intake of $P$ was $0.32 \mathrm{I} g$. and was similar to that attained by the low-P sheep in Exp. I, namely $0.345 \mathrm{~g}$. It probably represents the minimum intake for maintenance on this particular diet.

It will be noted that an increase occurred in the digestibility of the dry matter in the P-supplemented sheep, in spite of the fact that the intake of dry matter was so much higher in this group.

Exp. 3. The results for the short 6-day trial, where sheep nos. 6, 13 and $\mathrm{I} 2$ were given vitamin $\mathrm{D}$ at the dose rate of 20,000 i.u. $/ \mathrm{kg} .24 \mathrm{hr}$. before the experiment began, are given in Table 3 .

Table 3. Exp. 3. Digestibility of dry matter and mean daily retention of phosphorus by the sheep over 6 days

\begin{tabular}{|c|c|c|c|c|c|}
\hline \multirow[b]{2}{*}{$\begin{array}{c}\text { Sheep } \\
\text { no. }\end{array}$} & \multirow[b]{2}{*}{ Diet } & \multicolumn{3}{|c|}{ Dry matter } & \multirow{2}{*}{$\begin{array}{c}\text { Retention } \\
\text { of } P \\
\text { (g.) }\end{array}$} \\
\hline & & $\begin{array}{l}\text { Intake } \\
(\mathrm{g} .)\end{array}$ & $\begin{array}{l}\text { Output } \\
\text { (g.) }\end{array}$ & $\begin{array}{l}\text { Digestibility } \\
(\%)\end{array}$ & \\
\hline $\begin{array}{c}1 \\
2 \\
14\end{array}$ & $\begin{array}{l}\text { Low-P (sheep rachitic) } \\
\text { High-P (sheep normal) }\end{array}$ & $\begin{array}{l}\left\{\begin{array}{l}265 \cdot 5 \\
277 \cdot 5\end{array}\right. \\
405 \cdot 7\end{array}$ & $\begin{array}{l}46 \cdot 0 \\
49 \cdot 6 \\
68 \cdot 7\end{array}$ & $\begin{array}{l}82 \cdot 7 \\
82 \cdot 2 \\
83 \cdot 0\end{array}$ & $\begin{array}{l}+0.048 \\
+0.064 \\
-0.164\end{array}$ \\
\hline $\left.\begin{array}{r}6 \\
13\end{array}\right\}$ & Low-P (sheep rachitic) & $\left\{\begin{array}{l}368 \cdot 6 \\
38 \mathrm{r} \cdot 3\end{array}\right.$ & $\begin{array}{l}68 \cdot 7 \\
73 \cdot 8\end{array}$ & $\begin{array}{l}81 \cdot 4 \\
80 \cdot 6\end{array}$ & $\begin{array}{l}+0.137 \\
+0.084\end{array}$ \\
\hline 12 & $\begin{array}{l}\text { High-P (sheep normal); all these } \\
\text { three received vitamin } D_{8}\end{array}$ & $476 \cdot 0$ & $88 \cdot I$ & $8 I_{4} \cdot 4$ & -0.387 \\
\hline
\end{tabular}

The low intakes of sheep nos. I and 2 were due to a reduction in appetite which followed injection of the ${ }^{32} \mathrm{P}$, although the dose was well within what are thought to be safe limits, and the sheep lost weight during the trial. This reduced intake was probably the reason for the raised digestibility of the dry matter for these sheep, since in this they were comparable to the sub-maintenance sheep in Exp. $\mathbf{r}$. 
'The negative balances of both high-P sheep were surprising and may be related to the fact that their food consumption was only half that of previously studied high-P sheep. The rachitic sheep given vitamin $D$ (nos. 6 and 13 ) retained more $P$ than the unsupplemented sheep (nos. I and 2), but since the food intake of nos. 6 and 13 was so much higher than that of the other two, it cannot be stated whether this higher retention was due to these sheep being less subject to the radiotoxic effect of ${ }^{32} \mathrm{P}$, or to a direct effect of the vitamin upon appetite. The evidence from sheep no. 4 in Exp. 4 supports the latter possibility.

Exp. 4. After the first ro-day experimental period, the one sheep used in this experiment was left just over a month before the second period. At an interval of $12 \mathrm{hr}$. before the second period began $1,000,000$ i.u. vitamin $D_{2}$ were given subcutaneously. The results are summarized in Table 4.

\begin{tabular}{|c|c|c|c|c|c|c|c|c|}
\hline & \multicolumn{4}{|c|}{ Before administration of vitamin $D_{2}$} & \multicolumn{4}{|c|}{ After administration of vitamin $\mathrm{D}_{2}$} \\
\hline & $\begin{array}{c}\text { Intake } \\
\text { (g.) }\end{array}$ & $\begin{array}{l}\text { Output } \\
\text { (g.) }\end{array}$ & $\begin{array}{c}\text { Re- } \\
\text { tention } \\
(\mathrm{g} .)\end{array}$ & $\begin{array}{c}\text { Digesti- } \\
\text { bility } \\
(\%)\end{array}$ & $\begin{array}{l}\text { Intake } \\
\text { (g.) }\end{array}$ & $\begin{array}{l}\text { Output } \\
\text { (g.) }\end{array}$ & $\begin{array}{l}\text { Ke- } \\
\text { tention } \\
\text { (g.) }\end{array}$ & $\begin{array}{c}\text { Digesti- } \\
\text { bility } \\
(\%)\end{array}$ \\
\hline $\mathrm{P}$ & 0.297 & 0.264 & 0.033 & - & 0.291 & 0.242 & 0.049 & - \\
\hline Dry matter & $356 \cdot 0$ & $75 \cdot 7$ & 一 & $78 \cdot 7$ & $320 \cdot 2$ & $63 \cdot 96$ & - & $80 \cdot 0$ \\
\hline
\end{tabular}

The evidence from this sheep supports the finding in the earlier experiments that the effect of a massive dose of vitamin $D_{2}$ is to increase both $P$ retention and the apparent digestibility of the dry matter.

\section{DISCUSSION}

On the low level of $\mathrm{P}$ intake in these experiments, the total urinary $\mathrm{P}$ was only $\mathrm{I}-2 \%$ of the quantity in the faeces. There was no alteration in the urinary $P$ level following vitamin $D_{2}$ administration. In the last experiment, for instance, the mean daily $P$ value in the urine both before and after administration of vitamin $D$, was $0.004 \mathrm{mg}$. $100 \mathrm{ml}$. Watson (1933) pointed out that the threshold value of $\mathrm{P}$ is high in sheep, and it was therefore not surprising to find that it was generally only in the sheep with a high $P$ intake that any measurable quantity of acid-soluble $P$ was found. The effect of the vitamin on the concentration of $P$ in the faeces varied somewhat with different sheep but was not pronounced, e.g. in sheep no. 4 , used in the last experiment, the effect was to increase the mean daily excretion by $15 \mathrm{mg} . / 100 \mathrm{~g}$.

It appears that the increase in both the $P$ retention and digestibility of dry matter which followed treatment with vitamin $D$ was achieved through a lowering of the total amount excreted relative to the intake. In view of the finding of Du Toit, Malan \& Rossouw (1930) that digestibility is unaltered by the level of $P$ intake, it was particularly interesting to find that the digestibility of dry matter for the rachitic sheep in the present work was raised when phosphate was added to the diet. The effect of the phosphate deficiency was not only to restrict the appetite and so the consumption of 
dry matter, but also the capacity to digest it. This recalls the work of Riddell, Hughes \& Fitch (1933) who found an increased metabolic rate in cows suffering from aphosphorosis and suggested that this might be the explanation of the lowered efficiency of food utilization originally observed in cattle by Theiler, Green \& Du Toit (r924).

The relative reduction in faecal dry matter which appears to follow massive dosing with vitamin $\mathrm{D}$ may in part be due to decrease in food residues following more efficient bacterial and protozoal breakdown in the rumen, wherein a more favourable nutrient medium may be provided by an increased rate of $P$ turnover through the saliva. It may also in part be due to a reduction in the number of dead microorganisms which, at least in non-ruminants, form the bulk of the dry matter of the faeces (Henry \& Kon, I939).

Investigations by Cohn \& Greenberg (1939) in the rat and by Shimotori \& Morgan (1943) in the dog lead to the conclusion that vitamin D supplementation in rachitic animals of these species does not cause an increase in the uptake of $P$ from the gut. The higher $P$ retention of the sheep treated with vitamin $D$ in the present work may indicate that in ruminants either increased absorption or decreased 'endogenous' excretion into the gut, or both, may occur when deficient animals are given vitamin D. Subsequent preliminary work, using radioactive $P$ (Ewer, 1952), indicated that the mechanism operating in the sheep is very complex.

\section{SUMMARY}

I. The results are reported of a small series of balance trials, designed to ascertain the effect of a single massive dose of vitamin $D_{2}$ on $P$ retention and on the digestibility of the dry matter eaten by normal and rachitic sheep.

2. Most of the rachitic sheep that maintained their weight were in negative $P$ balance.

3. The effect of giving one large dose of vitamin $D_{2}$ was to increase $P$ retention, and apparently the effect was sufficient in some instances to make negative balances positive.

4. The utilization of feed in terms of dry matter was increased approximately to the same degree by both high-P supplementation and dosing with vitamin $\mathrm{D}$.

\section{REFERENCES}

Bethke, R. M., Kick, C. H. \& Wilder, W. (1932). F. biol. Chem. 98, 389.

Burroughs, W., Gerlaugh, P. \& Bethke, R. M. (1950). I. Anim. Sci. 9, 207.

Cohn, W. E. \& Greenberg, D. M. (1939). F. biol. Chem. r3o, 625 .

Du Toit, P. J., Malan, A. I. \& Rossouw, S. D. (1930). Rep. vet. Res. S. Afr. no. 16, p. 313.

Ewer, T. K. (1951). Brit. F. Nutrit. 5, 287.

Ewer, 'Г. K. (1952). To be published.

Fiske, C. H. \& Subbarow, Y. (1925). 7. biol. Chem. 66, 375.

Fitch, L. W. N. \& Ewer, T. K. (1944). Aust. vet. Y. 20, 220.

Franklin, M. C. (1934-5). Rep. Inst. Anim. Path. Univ. Camb. no. 4, p. I 11.

Gomori, G. (1942). F. Lab. clin. Med. 27, 955.

Henry, K. M. \& Kon, S. K. (1939). Biochem. F. 33, 173.

McCollum, E. V., Simmonds, N., Parsons, H. T., Shipley, P. G. \& Park, E. A. (1920-1), Y. biol. Chem. 45,333 .

Riddell, W. H., Hughes, J. S. \& Fitch, J. B. (1933). Amer. F. Physiol. 106, 676. 
Sherman, H. C. \& Pappenheimer, A. M. (1920-1). Proc. Soc. exp. Biol., N.Y., 18, 193.

Shimotori, N. \& Morgan, A. F. (1943). F. biol. Chem. 147, 201.

Swift, R. W., Thacker, E. J., Black, A., Bratzler, J. W. \& James, W. H. (1947). J. Anim. Sci. 6, 432.

Theiler, A., Green, H. H. \& Du Toit, P. J. (r924). F. Dep. Agric. S. Afr. 8, 460.

Watson, R. H. (1933). Aust. F. exp. Biol. med. Sci. I1, 197.

\title{
Tryptophan Deficiency and Requirements in the Adult Rat
}

\author{
BY ANNE S. COLE AND W. ROBSON \\ Department of Physiology and Biochemistry, King's College, Strand, London, W.C. 2
}

(Received 25 October 1950)

Many investigations have been made in recent years on the nutritive value of protein hydrolysates and amino-acid mixtures. Nevertheless, it is doubtful whether these are complete substitutes for whole protein. The result of the first experiment reported here suggested that acid-hydrolysed casein supplemented with tryptophan was inadequate both for the maintenance of the adult female rat and for promoting recovery of animals suffering from severe tryptophan deficiency. However, the results of later experiments indicated that the supplemented hydrolysate was only slightly inferior in nutritive value to whole casein for adult, growing and tryptophan-deficient rats. In these experiments it was found possible to maintain adult rats at a constant, if not maximal, weight level on the acid-hydrolysed casein when it was supplemented with tryptophan, and an attempt was made to determine the maintenance requirement of the adult rat for tryptophan for comparison with values reported for the growing rat. At the same time the effects of prolonged tryptophan deficiency were studied, since it was thought that by using only adult animals it would be possible to distinguish between any specific effects that might be caused by this deficiency and those that were secondary to the general stunting.

\section{EXPERIMENTAL AND RESULTS}

\section{General}

Management of rats. 'The experiments were performed on hooded rats of the Lister strain. Litter-mates were used and divided into groups, as far as possible similar with regard to age, sex and weight. They were kept in individual cages with mesh bottoms placed in a tray containing sawdust (Exp. 1), or lined with blotting paper to absorb the urine (Exps. 2-4). This made it possible to collect the food that had been scattered and to determine the food intake. For the most part the faeces fell through the mesh; no extra precautions were taken against coprophagy.

Diets. In all the experiments the animals were fed $a d$ lib. The percentage composition of the basal diets was: casein (whole or hydrolysed) 14.7 , cystine 0.3 , starch 62 , hardened arachis oil ${ }_{5}$, lard 3 and salts 5 . The salt mixture had the following composition: $\mathrm{NaCl}_{5} \mathrm{I}^{\cdot} 9, \mathrm{MgSO}_{4} \cdot 7 \mathrm{H}_{2} \mathrm{O} \mathrm{I}_{4}, \mathrm{NaH}_{2} \mathrm{PO}_{4} \mathrm{IO} 4^{\cdot} \mathrm{I}, \mathrm{K}_{2} \mathrm{HPO}_{4} 286 \cdot 2, \mathrm{Ca}\left(\mathrm{H}_{2} \mathrm{PO}_{4}\right)_{2} \cdot \mathrm{H}_{2} \mathrm{O}$ I62, 